\title{
Relapse in patients with schizophrenia: a comparison between risperidone and haloperidol
}

\author{
Recaída em pacientes com esquizofrenia: uma comparação entre \\ risperidona e haloperidol
}

Eduardo Pondé de Sena, Rogério Santos-Jesus, Ângela Miranda-Scippa, Lucas de Castro Quarantini and Irismar Reis de Oliveira University Hospital Prof. Edgard Santos, Federal University of Bahia. Salvador, BA, Brazil

\begin{abstract}
Objectives: To compare rates of rehospitalization and time to relapse in risperidone vs. haloperidol-treated schizophrenic patients discharged from the hospital.

Methods: Randomized controlled trial comparing risperidone and haloperidol regarding relapse in patients with schizophrenia treated with flexible doses during one year.

Results: Twenty patients were assigned to risperidone and 13 to haloperidol. One patient from each group withdrew consent and one patient in the risperidone group was lost for follow-up. Six (30.0\%) patients in the risperidone group and $3(23.1 \%)$ in the haloperidol group relapsed $(p=1.00)$. However, time to relapse was shorter in the later (logrank $=4.2 ; p=.04)$. When rehospitalized, patients in the risperidone group stayed 34.5 days (median) at hospital as compared to the haloperidol group (median of 61 days) $(p=.61)$.

Conclusion: The proportion of schizophrenic patients who relapsed was similar in both groups; However, time to relapse was shorter in the haloperidol-treated patients.
\end{abstract}

Keywords Risperidone. Haloperidol. Antipsychotic. Schizophrenia. Relapse prevention.

Resumo Objetivos: Comparar taxas de re-hospitalização e o tempo para a recaída entre pacientes esquizofrênicos tratados com risperidona ou haloperidol após alta hospitalar.

Métodos: Ensaio controlado, randomizado, comparando risperidona e haloperidol em relação à recaída em pacientes com esquizofrenia tratados com doses flexíveis, com duração de um ano.

Resultados: Vinte pacientes foram alocados para a risperidona e 13 para o haloperidol. Um paciente em cada grupo retirou o consentimento e um tomando risperidona foi perdido para o seguimento. Seis $(30,0 \%)$ do grupo da risperidona e três $(23,1 \%)$ do grupo do haloperidol recaíram $(p=1.00)$. Contudo, o tempo até a re-hospitalização foi mais curto com o haloperidol (logrank $=4,2 ; p=0,04)$. Quando re-hospitalizados, os pacientes no grupo da risperidona permaneceram 34,5 dias no hospital (mediana) quando comparados com o grupo do haloperidol (mediana $=61$ dias $)(\mathrm{p}=0,61)$.

Conclusão: A proporção de pacientes esquizofrênicos que recaíram foi similar em ambos os grupos. Contudo, o tempo para a recaída foi mais curto nos pacientes tratados com haloperidol.

Descritores Risperidona. Haloperidol. Antipsicótico. Esquizofrenia. Prevenção de recaída.

\section{Introduction}

Schizophrenia is a chronic disorder with serious physical, social and economic consequences. ${ }^{1}$ The economic burden of schizophrenia was estimated in 33 billion dollars in the United States in $1990 .{ }^{2}$ Much of this cost can be attributed to the consequences of psychotic relapse. ${ }^{3}$ The disorder is usually char- acterized by relapses alternating with periods of full or partial remission. Although antipsychotic medication is effective in reducing relapse rates, $30 \%$ to $40 \%$ of patients relapse within 1 year after hospital discharge even if they are receiving maintenance medication. ${ }^{4-6}$

Most schizophrenic patients have a chronic course with many 
relapses characterized by exacerbation of psychosis and increase of rehospitalizations. ${ }^{7}$ Successive relapses can reduce the degree and duration of the following remission, worsen disability and increase refractoriness to future treatment. ${ }^{8}$ In order to prevent relapses, maintenance treatment has been mandatory for most schizophrenic patients. ${ }^{3}$ However, long-term treatments have generally been disappointing. ${ }^{10,11}$

Risperidone is an antipsychotic with potent serotonin-5HT2A and dopamine D2 receptor antagonism. ${ }^{12}$ The advantages of risperidone over conventional neuroleptics are related to a lower incidence of extrapyramidal symptoms (EPS) ${ }^{13}$ and a favorable profile on positive and, more important, negative symptoms of schizophrenia. ${ }^{13-15}$ Meta-analyses have suggested that risperidone has greater efficacy and fewer extrapyramidal effects than haloperidol. ${ }^{16-18}$ For the treatment of positive symptoms and for the depression-anxiety dimension of schizophrenia, risperidone was found to be superior to haloperidol. ${ }^{19}$

We report here the results of a comparison of risperidone versus haloperidol for the prevention of relapses in a Brazilian randomized controlled trial of schizophrenic patients. This study also examined the time to relapse of patients receiving risperidone and haloperidol who had been discharged from a state psychiatric hospital.

\section{Methods}

\section{Subjects}

This trial was performed in a Brazilian psychiatric hospital in Salvador, state of Bahia. Patients aged 15-40 with a DSMIII- ${ }^{20}$ diagnosis of schizophrenia were recruited between March 1995 and November 1997. Exclusion criteria were long hospitalization (12 months or more), other Axis I disorders, drug dependence within the last 12 months, significant neurological or organic disorders, who would be patients difficult to follow-up, participation in a trial during 4 weeks prior to the study, and use of depot neuroleptics with one treatment cycle before the start of the study.

\section{Study design}

In this flexible-dose, parallel-group, controlled trial, a simple randomization was performed by means of the computer's clock that assigned patients to risperidone or haloperidol according to even or odd numbers. Patients who met the study entry criteria entered a mandatory washout period which lasted for 3 to 7 days. During this washout period, any neuroleptic or anticholinergic treatment was discontinued, but the use of diazepam, when necessary, was allowed. After this period, concomitant medications, including association with other antipsychotics, were permitted in this naturalistic study. Patients were prescribed risperidone $1 \mathrm{mg}$ bid for the first day, then $2 \mathrm{mg}$ bid and $3 \mathrm{mg}$ bid for the second and third days. Flexible dose was then permitted according to clinical evaluation. Haloperidol was prescribed at the clinician discretion. Patients were assessed at admission, discharge, 6 months and 1 year.

This study was approved by the Institutional Review Board.
Written informed consent was obtained from the legal representative of all included patients.

\section{Relapse}

Relapse was defined as the first rehospitalization after discharge. We assessed time to relapse and the number of days patients remained rehospitalized.

\section{Statistical analysis}

Non-parametric tests were used for the statistical analyses. Chi-square or Fisher exact tests were used for categorical variables and the Mann-Whitney test for continuous data. Time to relapse, defined as the first rehospitalization after discharge was assessed by means of the logrank test. All statistical tests were two-tailed, and $p$-values were considered significant if $=.05$. Descriptive analyses were used for demographic data.

\section{Results}

We included 33 male patients (aged 17-40 years) with a diagnosis of schizophrenia according to the DSM-III-R, who were hospitalized due to an acute exacerbation. Twenty patients were assigned to risperidone and 13 to haloperidol. No demographic differences were seen between the two groups. Patients in both groups were similar regarding age at onset of schizophrenia (medians of 18.5 and 20.0 years, for risperidone and haloperidol, respectively; $\mathrm{p}=.34$ ), age of first hospitalization (19.5 and 21.0 years, for risperidone and haloperidol, respectively; $\mathrm{p}=.22$ ), number of previous hospitalizations (median $=1.0$ for both groups; $p=.92$ ) and length of current hospitalization before entering the study (median of 2.5 days for risperidone and 4.0 days for haloperidol; $\mathrm{p}=.91$ ). The neuroleptic dosage was 4.0

Table 1 - Demographic data.

\begin{tabular}{|c|c|c|c|}
\hline & $\begin{array}{l}\text { Risperidone } \\
\quad(n=20)\end{array}$ & $\begin{array}{l}\text { Haloperidol } \\
\qquad(n=13)\end{array}$ & $\mathrm{p}$ \\
\hline $\begin{array}{l}\text { Age, years } \\
\text { (median: minimum-maximum) }\end{array}$ & $\begin{array}{c}27.9 \\
18.4-40.1\end{array}$ & $\begin{array}{c}27.4 \\
17.2-39.0\end{array}$ & 0.80 \\
\hline \multicolumn{4}{|l|}{ Ethnicity, n (\%) } \\
\hline White & $4(21.1 \%)$ & $2(15.4 \%)$ & \\
\hline Mixed & $9(47.4 \%)$ & $2(15.4 \%)$ & \multirow[t]{2}{*}{0.09} \\
\hline Black & $6(31.6 \%)$ & $9(69.2 \%)$ & \\
\hline Onset of Schizophrenia, years & 18.5 & 20.0 & 0.34 \\
\hline (median: minimum-maximum) & $15.0-25.0$ & $14.0-28.0$ & \\
\hline Age of first hospitalization, years & 19.5 & 21.0 & 0.22 \\
\hline (median: minimum-maximum) & $16.0-28.0$ & $17.0-28.0$ & \\
\hline Number of previous hospitalizations & 1.0 & 1.0 & 0.92 \\
\hline (median: minimum-maximum) & $0.0-40.0$ & $0.0-20.0$ & \\
\hline Length of current hospitalization, days & 2.5 & 4.0 & 0.91 \\
\hline (median: minimum-maximum) & $1.0-34.0$ & $1.0-9.0$ & \\
\hline Neuroleptic dosage, mg & 4.0 & 10.0 & - \\
\hline (median: minimum-maximum) & $1.0-6.0$ & $5.0-17.0$ & \\
\hline
\end{tabular}

Table 2 - Characteristics of relapses.

\begin{tabular}{lccc}
\hline & $\begin{array}{c}\text { Risperidone } \\
(\mathrm{n}=20)\end{array}$ & $\begin{array}{c}\text { Haloperidol } \\
(\mathrm{n}=13)\end{array}$ & $\mathrm{p}$ \\
\hline $\begin{array}{l}\text { Number of patients that were hospitalized }(\%) \\
\text { Time (days) for first rehospitalization }\end{array}$ & $6(30.0)$ & $3(23.1)$ & 1.00 \\
after discharge & 103.0 & 28.0 & 0.12 \\
(median: minimum-maximum) & $14.0-312.0$ & $27.0-54.0$ & \\
$\begin{array}{l}\text { Duration of first rehospitalization (days) } \\
\text { (median: minimum-maximum) }\end{array}$ & 34.5 & 61.0 & 0.61 \\
\hline
\end{tabular}




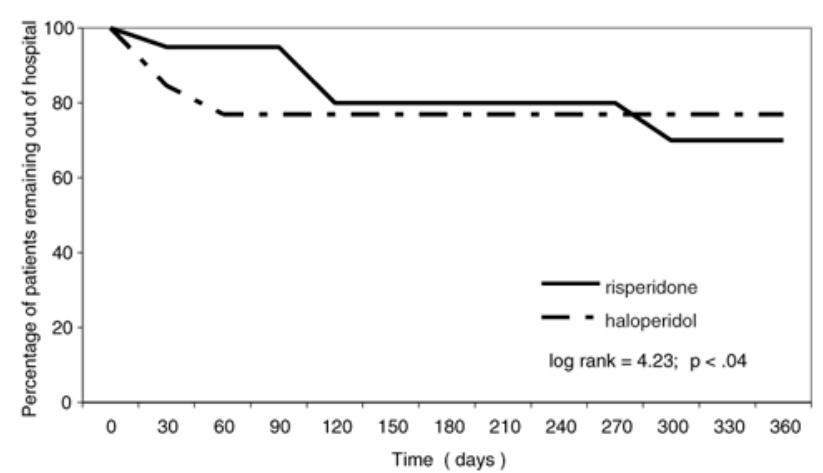

$\overline{\text { Figure - Time course to rehospitalization of discharged patients with }}$ schizophrenia taking risperidone or haloperidol.

mg (median) for risperidone and $10.0 \mathrm{mg}$ (median) for haloperidol (Table 1). One patient in the risperidone group and one in the haloperidol one withdrew consent. Another patient receiving risperidone was lost for follow-up.

Six patients $(30 \%)$ in the risperidone group, and $3(23.1 \%)$ in the haloperidol one relapsed $(p=1.00)$. However, the patients in the risperidone group took 103.0 days (median) to rehospitalization as compared to patients in the haloperidol group ( median $=28.0)$ (logrank $=4.2 ; p=.04)$ (Figure).

There were no differences in the duration of their first rehospitalization after discharge, (medians of 34.5 days for the risperidone group and 61.0 for the haloperidol one; $\mathrm{p}=.61$ ). Table 2 illustrates the characteristics of relapses.

\section{Discussion}

To our knowledge, this is the first Brazilian prospective study comparing patients taking an atypical neuroleptic and a conventional drug regarding rehospitalization rates and evaluating the risk of relapse of discharged patients with schizophrenia. Time to relapse seen in Fig. suggests that risperidone may be superior to haloperidol in protecting schizophrenic patients against early rehospitalization.

The other existing Brazilian study evaluating the impact of risperidone in reducing hospitalization rates of patients with schizophrenia or schizoaffective disorder was retrospective. ${ }^{21}$ The authors found that the drug can be useful for patients with multiple hospitalizations, with a positive impact in the costbenefit ratio and in economic aspects, when compared to treatment with conventional antipsychotics.
Up to half of all stabilized schizophrenic patients may be rehospitalized within one year after discharge. ${ }^{22}$ It has been suggested that the more relapses and periods without medication, the poorer the prognosis and long-term outcome for schizophrenic patients. ${ }^{23}$ The present study suggests that treatment with haloperidol is associated with a shorter time to relapse, as compared with treatment with the atypical agent, risperidone.

Although the study by Addington et $\mathrm{al}^{24}$ indicated that risperidone treatment results in a reduction in hospital days and one recent study showed that risperidone treatment is associated with a significantly lower relapse rate than haloperidol in adult outpatients with clinically stable schizophrenia or schizoaffective disorder, ${ }^{25}$ our data did not confirm such findings. However, this study, which showed no differences in relapse rates and number of days staying in hospital, was limited by a too small sample size.

The outcome data for conventional antipsychotics reported by Hogarty ${ }^{26}$ estimates recidivism rates of $37 \%$ at 12 months and $55 \%$ at 24 months. In a study of patients treated with standard doses of fluphenazine decanoate plus either supportive or intensively applied family therapy, Schooler et $\mathrm{al}^{27}$ reported that $19 \%-31 \%$ of the patients relapsed within a 2 -year period.

Results of other studies suggested superiority of the atypical over conventional drugs. In a post-hoc analysis of a large randomized controlled trial, Rabinowitz \& Davison ${ }^{28}$ suggested that risperidone could be more effective than haloperidol in long-stay schizophrenic inpatients. Another report comparing risperidone with atypical clozapine concluded that rates of rehospitalization of patients discharged on a regimen with these atypical drugs are lower than previously reported with conventional antipsychotics. ${ }^{29}$

Another report by Rabinowitz et $\mathrm{al}^{30}$ examined time to readmission over 2 years for patients discharged from inpatients facilities in Israel, while taking risperidone $(n=268)$, olanzapine $(n=313)$ or conventional neuroleptics $(n=458)$ and found that $67 \%$ of patients taking risperidone and $69 \%$ of those taking olanzapine remained discharged, as compared to $52 \%$ of those taking conventional drugs. Their results suggested that rehospitalization rates of patients taking the atypical antipsychotics risperidone and olanzapine do not differ from each other but are considerably lower than the rates for patients treated with conventional antipsychotic drugs.

As a conclusion, the ratio of schizophrenic patients who relapsed in the present study was similar in both groups, however time to relapse was shorter in the haloperidol-treated patients.

\section{References}

1. Buckley PF. Treatment of schizophrenia: let's talk dollars and sense. Am J Manag Care 1998;4:369-83.

2. Rice DP. The economic impact of schizophrenia. J Clin Psychiatry 1999;60:Suppl 1:4-6.

3. Weiden PJ, Olfson M. Cost of relapse in schizophrenia. Schizophr Bull 1995;21:419-29.

4. Davis JM. Overview; maintenance therapy in psychiatry, I: schizophrenia. Am J Psychiatry 1975;132:1237-45.

5. Hogarty GE, Schooler NR, Ulrich R, Mussare F, Ferro P, Herron E. Fluphenazine and social therapy in the aftercare of schizophrenic patients: relapse analyses of a two-year controlled study of fluphenazine decanoate and fluphenazine hydrochloride. Arch Gen Psychiatry 1979;36:1283-94.

6. Hogarty GE, Ulrich RF. The limitations of antipsychotic medication on schizophrenia relapse and adjustment and the contributions of psychosocial treatment. J Psychiatry Res 1998;32:243-50.

7. Andreasen NC. Symptoms, signs and diagnosis of schizophrenia. Lancet 1995;346:477-81. 
8. Wyatt RJ. Neuroleptics and the natural course of schizophrenia. Schizophr Bull 1991;17:325-51.

9. Kane JM. Pharmacologic treatment of schizophrenia. Biol Psychiatry 1999;46:1396-408.

10. Herz MI, Lamberti JS, Mintz J, Scott R, O’Dell SP, Mc Cartan L, et al. A program for relapse prevention in schizophrenia: a controlled study. Arch Gen Psychiatry 2000;57:277-83.

11. Ayuso-Gutierrez JL, del Rio Vega J. Factors influencing relapse in the long-term course of schizophrenia. Schizophr Res 1997;28:199-206.

12. Janssen PAJ, Niemegeers, CJE, Awouters F, Schellekens KH, Megens AAHP, Meert TF Pharmacology of risperidone (R 64 766), a new antipsychotic with serotonin-S2 and dopamine-D2 antagonistic properties. J Pharmacol Exp Ther 1988;244:685-93.

13. Peuskens J. Risperidone in the treatment of patients with chronic schizophrenia: a multi-national, multi-centre, double-blind, parallel-group study versus haloperidol. Br J Psychiatry 1995;166(6):712-26.

14. Chouinard G, Jones B, Remington G, Bloom D, Addington D, MacEvan GW, et al. A Canadian multicenter placebo-controlled study of fixed doses of risperidone and haloperidol in the treatment of chronic schizophrenic patients. J Clin Psychopharmacology 1993;13:25-40.

15. Marder SR, Meibach RC. Risperidone in the treatment of schizophrenia. Am J Psychiatry 1994;151:825-35.

16. De Oliveira, Miranda-Scippa AM, de Sena EP, Pereira EL, Ribeiro MG, de Castro-e-Silva E, et al. Risperidone versus haloperidol in the treatment of schizophrenia: a meta-analysis comparing their efficacy and safety. J Clin Pharm Ther 1996;21:349-58.

17. Song F. Risperidone in the treatment of schizophrenia: a meta-analysis of randomized controlled trials. J Psychopharmacol 1997;11:65-71.

18. Davies A, Adena MA, PC, Keks NA, Catts SV, Lambert T, Scweitzer I. Risperidone versus haloperidol: I. Meta-analysis of efficacy and safety. Clin Ther 1998;20(1):58-71.

19. Marder SR, Davis JM, Chouinard G. The effects of risperidone on the five dimensions of schizophrenia derived by factor analysis: combined results of the North American trials. J Clin Psychiatry 1997;58:538-46.

20. American Psychiatric Association. Diagnostic and Statistical Manual of Mental Disorders [revised]. 3rd edition. Washington (DC): APA; 1987.
21. Lima MS, Mari JJ, Trefiglio RP, Bacaltchuk J. Impacto do uso da risperidona na hospitalização de pacientes esquizofrênicos: estudo retrospectivo em três cidades brasileiras. J Bras Psiq 1999;48:461-4.

22. Weiden P, Aquila R, Standard J. Atypical antipsychotic drugs and longterm outcome in schizophrenia. J Clin Psychiatry 1996;57:53-60.

23. Sheitman BB, Lee H, Strauss R, Lieberman JA. The evaluation and treatment of first-episode psychosis. Schizophr Bull 1997;23:653-61

24. Addington DE, Jones B, Bloom D, Chouinard G, Remington G, Albright P. Reduction of hospital days in chronic patients who have schizophrenia treated with risperidone: a retrospective study. Clin Ther 1993;15:917-26.

25. Csernansky JG, Mahmoud R, Brenner R for the Risperidone-USA-79 Study Group. A comparison of risperidone and haloperidol for the prevention of relapse in patients with schizophrenia. N Engl J Med 2002;346:16-21.

26. Hogarty GE. Prevention of relapse in chronic schizophrenic patients. J Clin Psychiatry 1993;54(3 Suppl):18-23.

27. Schooler NR, Keith SJ, Severe JB, Matthew SM, Bellack AS, Glick ID, et al. Relapse and rehospitalization during maintenance treatment of schizophrenia. Arch Gen Psychiatry 1997;54:453-63.

28. Rabinowitz J, Davidson M. Risperidone versus haloperidol in long-term hospitalized chronic patients in a double blind randomized trial: a post hoc analysis. Schizophr Res 2001;50:89-93.

29. Conley RR, Love RC, Kelly DL, Bartko JJ. Rehospitalization rates of patients recently discharged on a regimen of risperidone or clozapine. Am J Psychiatry 1999;156:863-8.

30. Rabinowitz J, Lichtenber P, Kaplan Z, Mark M, Nahon D, Davidson M. Rehospitalization rates of chronically ill schizophrenic patients discharged on a regimen of risperidone, olanzapine or conventional neuroleptics. Am J Psychiatry 2001;158:266-9.

\section{Correspondência:}

Eduardo Pondé de Sena

Rua Humberto de Campos, 144 sala 303

40150-130 Salvador, BA, Brasil

E-mail:eduponde@ufba.br 